\title{
Letter to the editor: Engaging (but not "educating") the public in technology developments may contribute to a socially sustainable dairy industry
}

\author{
Maria J. Hötzel ${ }^{1}$ \\ Laboratório de Etologia Aplicada e Bem-Estar Animal, Universidade Federal de Santa Catarina, Rodovia Admar Gonzaga, 1346, Itacorubi, \\ Florianópolis, SC 88.034-001, Brazil
}

In a well-conducted and analyzed survey of German consumers, Pieper et al. (2016) found that the majority of respondents lacked basic knowledge about milk production and had negative perceptions toward the use of sexed semen, embryo transfer, hormone treatment to increase dairy cows' fertility, and cloning. This led the authors to conclude that there is a need to educate consumers to inform them about dairy production and modern farm management practices. The rationale for this would be to prevent a scenario where the use and future development of reproductive technologies could be made difficult via (1) consumers' buying choices, and (2) concerned citizens' political support to restrictive regulations.

I agree that society's lack of knowledge and misconceptions in issues of agriculture must be addressed, but education campaigns are unlikely to improve public acceptance of reproductive technologies in food animal production. The first reason is that this approach is based on the outdated although still popular (Bauer, 2016) "deficit model": as ignorance is the basis for a lack of societal support for issues in science and technology, reducing ignorance should bring public opinion into line with expert opinion (Hansen et al., 2003; Simis et al., 2016). This view ignores, for example, the fact that non-experts assess risk differently from experts (Hansen et al., 2003; Macnaghten, 2004) and that moral values strongly contribute to society's attitudes toward dairy production (Boogaard et al., 2011; Cardoso et al., 2016). Second, any education campaign may bring to light some issues not covered in their paper; for example, why are so many dairy cows subfertile -are they sick or past their metabolic limits? Do estrus synchronization, embryo transfer, and cloning raise any animal welfare concerns? If not in the milk, is there a risk of hormone residues in the environment? How often are these reproductive technologies used for human convenience or profitability? These issues, which

Received May 3, 2016.

Accepted June 16, 2016.

${ }^{1}$ Corresponding author: maria.j.hotzel@ufsc.br may represent acceptable trade-offs to many scientists, may be contentious to the public.

Providing people with information on a new technology (e.g., transgenic animals, Macnaghten, 2004) or contentious husbandry practices (e.g., early cow-calf separation, Ventura et al., 2013; zero-grazing for dairy cows, Schuppli et al., 2014) does not result in high rates of approval. Informing the public may be effective in improving attitudes toward new technologies that are presented as alternatives to practices used by the industry and that are perceived as negative for animal welfare (Tuyttens et al., 2011) but, in other cases, may in fact increase opposition to established practices (Ryan et al., 2015). For some people, it may uncover aspects of the production system they ignored and that contradict their expectations (Ventura et al., 2016).

The interests of the public-primarily attending the growing demand for food while preserving the environment - are presented as the main argument to support the development and use of new technologies in agriculture (Godfray and Garnett, 2014). This entails that all interests of the public should be considered, including those of a moral nature. Rather than educating the public, engaging it in the development of new technologies in agriculture is likely to yield a more socially sustainable future for dairy production. Several examples of engagement methodologies that have been evaluated experimentally in the context of food animal production (e.g., Swanson et al., 2011) and other industries (e.g., Jellema and Mulder, 2016) can be explored for the case under discussion. In essence, these methodologies involve public participation and create opportunities for all parties to listen and be listened to, and to understand and perhaps respond to the perspectives of others.

\section{ACKNOWLEDGMENTS}

I do not act as a consultant or receive funding from any association of producers, animal protection organization, or companies that produce or market any food animal products. I am not opposed in principle to the 
use or development of reproductive technologies for animal production.

\section{REFERENCES}

Bauer, M. W. 2016. Results of the essay competition on the 'deficit concept'. Public Underst. Sci. 25:398-399.

Boogaard, B. K., S. J. Oosting, B. B. Bock, and J. S. C. Wiskerke. 2011. The sociocultural sustainability of livestock farming: An inquiry into social perceptions of dairy farming. Animal 5:1458-1466.

Cardoso, C. S., M. J. Hötzel, D. M. Weary, J. A. Robbins, and M. A G. von Keyserlingk. 2016. Imagining the ideal dairy farm. J. Dairy Sci. 99:1663-1671.

Godfray, H. C. J., and T. Garnett. 2014. Food security and sustainable intensification. Philos. Trans. R. Soc. Lond. B Biol. Sci. 369:20120273.

Hansen, J., L. Holm, L. Frewer, P. Robinson, and P. Sandøe. 2003. Beyond the knowledge deficit: Recent research into lay and expert attitudes to food risks. Appetite 41:111-121.

Jellema, J., and H. A. J. Mulder. 2016. Public engagement in energy research. Energies 9:125. http://dx.doi.org/10.3390/en9030125.

Macnaghten, P. 2004. Animals in their nature: A case study on public attitudes to animals, genetic modification and 'Nature'. Sociology $38: 533-551$.
Pieper, L., M. G. Doherr, and W. Heuwieser. 2016. Consumers' attitudes about milk quality and fertilization methods in dairy cows in Germany. J. Dairy Sci. 99:3162-3170.

Ryan, E. B., D. Fraser, and D. M. Weary. 2015. Public attitudes to housing systems for pregnant pigs. PLoS ONE 10:e0141878.

Schuppli, C. A., M. A. G. von Keyserlingk, and D. M. Weary. 2014 Access to pasture for dairy cows: Responses from an online engagement. J. Anim. Sci. 92:5185-5192.

Simis, M. J., H. Madden, M. A. Cacciatore, and S. K. Yeo. 2016. The lure of rationality: Why does the deficit model persist in science communication? Public Underst. Sci. 25:400-414.

Swanson, J. C., Y. Lee, P. B. Thompson, R. Bawden, and J. A. Mench. 2011. Integration: Valuing stakeholder input in setting priorities for socially sustainable egg production. Poult. Sci. 90:2110-2121.

Tuyttens, F. A. M., F. Vanhonacker, K. Langendries, M. Aluwe, S. Millet, K. Bekaert, and W. Verbeke. 2011. Effect of information provisioning on attitude toward surgical castration of male piglets and alternative strategies for avoiding boar taint. Res. Vet. Sci 91:327-332.

Ventura, B. A., M. A. G. von Keyserlingk, C. A. Schuppli, and D. M. Weary. 2013. Views on contentious practices in dairy farming: The case of early cow-calf separation. J. Dairy Sci. 96:6105-6116.

Ventura, B. A., M. A. G. von Keyserlingk, H. Wittman, and D. M. Weary. 2016. What difference does a visit make? Changes in animal welfare perceptions after interested citizens tour a dairy farm. PLoS ONE 11:e0154733. 